\title{
ERUDITE PEDAGOGIC PRAXIS OF EXTENSION PARADIGM FOR TECHNOLOGICAL SKILLS TRANSFER OF THE EMERGING FARMERS
}

\author{
Teele, $T^{1}$, Nkoane, $M_{.}^{2}$ and Mahlomaholo, $S .^{3}$ \\ Correspondence author: T. Teele, Email: tspoteele@yahoo.com
}

\begin{abstract}
Technological skills transfer approach from extension practitioners to the emerging farmers plays a significant role in the educational developments of the emerging farmers. These approaches have to take into account the methods of teaching that are in line with what is acceptable and underpinned by the adult teaching and learning approaches. Agricultural extension as an educational development programme for the emerging farmers needs to borrow from these approaches. Emerging farmers and extension practitioners in South Africa are mostly a group of diverse adults from different backgrounds and varying political, economic and social statuses. The formal education status of the emerging farmers might play a role in the ability to consume and apply presented information on the farm. However, the manner or approach that the information is presented could determine whether the emerging farmer become resistant to the information or not. The study employed the Participatory Action Research methodology with the philosophical framing of Bricolage to generate data that was analysed using Critical Discourse Analysis. The emerging farmers and extension practitioners volunterily engaged in the emancipatory discourse to outline the learning challenges using agricultural extension methods. Presenting agricultural information to the emerging farmers in the form of the Basic Education pedagogy, undermine the adult education prerequisites for the emerging farmers during training and farm visits. The emerging farmers, as adults exposed to agricultural extension, has to be conducted so guided by the trialled and tested adult education principles. By law, every individual over 15 years of age are entitled to adult education. The extension practitioners need to be acquainted with the adult education perspective.
\end{abstract}

Keywords: Technological skills transfer, Emerging farmers, Extension, Pedagogic praxis

\section{INTRODUCTION}

Agricultural extension services in South Africa is an informal education process which emerging farmers are provided with information by extensionists/extension practitioners with intentions to improve their farming techniques and approaches (Dube, 1993:18). When effectively and efficiently applied, extension services will capacitate the emerging farmers with the knowledge to increase production competence and revenue, improving their standard of living and lifting their social and learning standards (Oladosu, 2006:117; Teele et al., 2020:8). It consists of communicating the information to assist the farming community in creating sound

\footnotetext{
${ }^{1}$ Lecturer: Organisational Training and Development, Higher Education, Boston City Campus, 19 Elekton Rd, Techno Park, Stellenbosch, 7600; Email: tspoteele@yahoo.com, ORCID: 0000-0001-5267-7652

2 Deputy Dean: Research and Internationalisation, Private Bag X1001, KwaDlangezwa 3886, University of Zululand, Tel: +27 (0)35 902 6682, Email: Nkoanem@unizulu.ac.za.

${ }^{3}$ Deputy Vice-Chancellor: Teaching and Learning, Private Bag X1001, KwaDlangezwa 3886, University of Zululand, Tel: +27 (0)35 902 6634, Email: mahlomaholom@unizulu.ac.za
} 
ideas and making informed decisions (Hossain et al., 2018:128). The critical issue is the type of technological skills transfer used in conveying information to the emerging farmers. Extension educational activities include the dissemination of information to emerging farmers through newsletters, newspaper articles, television and radio broadcasts, and the utilisation of other media (Tiraieyari et al., 2010:5380). Printed materials such as magazines, bulletins, fact sheets, and books, all contribute to the educational process (Johnson et al., 2008:3). Since the extension is a process of getting useful information to farmers to help them acquire knowledge, skill and attitude and to implement this information effectively, extensionists, therefore, should be competent in using a variety of teaching methods as a tool in training emerging farmers. Extension plays a vital role in the farming progress of emerging farmers.

Agricultural extension has shifted their principal focus from agricultural productivity towards sustainable development, where participatory processes, action learning- that is, the human dimension of agricultural and natural resource management are given the priority. The proficiency of agricultural extension work enormously depends on the extension professionals' mastery of the work of extension on linking emerging farmers to the relevant assistance that they need then. Included are skilled, inspired, dedicated and quick to respond to the everchanging social, economic and political environment (Martin \& Bin Sajilan, 1989:71). The improved extension services for the emerging farmers have to be regulated at the policy level. The delivery of agricultural technological skills and research knowledge transferred to the emerging farmers and other users is not mostly in a simple and understandable form (Dyer \& Osborne, 1996;39). Inadequate teaching knowledge of the extension practitioners was the leading cause for not successfully instilling teaching perceptions (Tiraieyari et al., 2010:5382); thus, emerging farmers may not gain noticeable educational results from agricultural education training programmes (Buriak \& Shinn, 1989:14). This study investigated the patterns in the extension approaches that extensionists/extension practitioners use to disseminate information and transfer technological skills to the emerging farmers. At the same time, it suggests the infusion of the trailed and tested adult education approach into the extension methods when engaging in the educational programmes with the emerging farmers.

\section{THEORETICAL FRAMEWORK}

Bricolage metaphor as a theory of choice defines how post-colonial and post-positivist or postmodernist or post-structuralist methods have advanced scholars to establish various, multitheoretical and multi-methodological perspectives in knowledge production in qualitative research (Li et al., 2015:26; Sehring, 2009:65). It takes a real consideration at dominated viewpoints; not in some inexperienced, impractical manner but a rough and precarious orientation (Kincheloe, 2001:693). It builds a much more active role for co-researchers in bringing co-researchers together in changing reality and in crafting the research procedures and narratives that it represents (Kincheloe \& Berry, 2004:39). Bricolage uses pure multidisciplinary research to merge together research knowledge perspective with field-based as well as interpretative contexts as a practice (Kincheloe, 2001:690). Theoretical understanding of bricolage further indicates that it aimed to increase research techniques and build an approach of education knowledge. It exists out of respect for the complexity in knowledge management and entrepreneurship (Hubík, 1997:58; Séverine Le, 2005:2). The theory underpinning this study was based on bricolage focusing on the social constructivism principles. Bricolage assigns the ways of constructivists that separate it from the naive realism 
of the positivists, the critical realism of the post-positivists, and the historical realism of the critical theorists, in favour of relativism, based on various psychological constructions conveyed by collectives and individuals ( $\mathrm{Au}, 1998: 299$; Mahlomaholo, 2013:4697; Balina et $a l ., 2015: 116)$. Rhetoric is the art of spoken or written words which are essential and useful. It generally refers to how language is employed, but it has come to mean the insincere or even deceptive use of words. In this study, the researcher refers to fellow research 'participants' as co-researchers, not as objects (Owusu\& Janssen, 2013:19). This study takes into account that co-researchers are human beings with emotions and feelings.

\section{METHODOLOGY}

McTaggart (1994:315) describes Participatory Action Research (PAR) in spiral steps consisting of planning, action, observation and the evaluation of the result of the action (Bergold \& Thomas, 2012:17). PAR is a societal procedure of cooperative learning that is achieved by groups of individuals, who collectively attempt to alter through applications that they engage in the social world (Kemmis \& McTaggart, 2000:569). PAR developed as an approach that allows researchers to participate in a co-partnership relationship with people in a way that advances people's desire to act for transformation and emancipate. Participatory action research as a methodology is known to emphasise on the research that allows for action to take form. It pays careful attention to power relationships and distinctions, with fewer selfmotivated methods that eliminate information and evidence from their frameworks. A consideration of the procedure of self-production emerges beyond the formalist rationale, as its dedication to the recommended processes continuously involve more significant issues of determination in the concentration on matters of human dignity, independence, power, and social justice (Kincheloe, 2001:682). Post-formalism within participatory action research involves various methods of documentation being video or voice recording, of what we are doing and our findings have to be documented (Crane, 2011:5), using written reports or a communication medium.

Data was generated using SWOT analysis reflecting on the strengths, weaknesses, opportunities and threats, that we are going to focus on was selected and used to formulate a strategic plan. The combined use of the theoretical framework and the methodology was appropriate, which appropriately drew on the models of critical theory and constructivism paradigm and used a variety of qualitative and quantitative methods (Crotty, 1998:187). The study included full participatory engagement with local emerging farmers and extension practitioners at institutions of agricultural training facilities and farms. All participants were participating voluntarily as research partners (co-researchers), accomplishing the enablement of those associated with the project (Baum et al., 2010:856). The fundamental decision is not to treat the research partners as objects of research but rather, as co-researchers (Bergold\& Thomas, 2012:1). The co-researchers might have limited material resources at their disposal, but all participants are involved as knowing subjects who bring their perspectives to the knowledge-production process. Ethical clearance was electronically applied for as required by the university and approved by the University of the Free State Ethical Committee for ethical consideration with the ethical clearance number UFS-HSD2016/1186. 


\section{DATA ANALYSIS, INTERPRETING AND REPORTING}

Text and talk were analysed using Critical Discourse Analysis (CDA), which is engaged with reviewing and analysing transcribed and verbal texts to disclose the discursive bases of power, inequality, dominance and bias (van Dijk, 1998:127). Tape, audio and video recording of routine interactions and written texts constituted the data of the study (Paräkylä \& Ruusuvuori, 2011:529). Attention was paid to all levels and dimensions of the discourse of communicative events (de Beaugrande, 2006:33), as well as their interpretation and understanding (Van Dijk, 1995:21). Critical discourse analysis was assigned for data analysis, looking at the textual, semantics, discursive and social functions. CDA has its authority to fascinate and trouble, and its most inspiring qualities and flaws have created argument and discrepancy (Hidalgo Tenorio, 2011:201; Van Dijk, 1997:131; Wodak \& Meyer, 2009:11). It describes, explains and eradicates delusion, by revealing structures of power and ideologies behind discourse; that is, by making visible, causes that are hidden (de Beaugrande, 2006: 36; Janks, 1997:340). Critical discourse analysis also includes underlying ideologies that play a role in the reproduction of or resistance against dominance or inequality (van Dijk, 1996:18) in studying social phenomena that are necessarily complex and thus require a multidisciplinary and multi-methodical approach.

\section{FINDINGS}

The evidence reveals that emerging farmers are not allowed to participate in the planning and development of their learning activities. The outdated traditional top-down approach is practised from the extension practitioners' seniors when it comes to dealing with the educational requirements of emerging farmers. The emerging farmers have indicated that during technology transfer, that, they are expected to master the technologies which they have no practical demonstrations or full training and exposure to such techniques. The extension practitioners indicated that emerging farmers are not following their instructions as to their advisors. Though, it became clear that the technologies and information that the extension practitioners bring to the emerging farmers, there were no engagements during planning between the emerging farmers and the extension practitioners as well as between extension practitioners and their seniors. It became evident that the emerging farmers are aware that on their own, they will not realise their goals. They are adamant that without the perspective of all those involved, the most accurate responses or answers will not be achieved.

\section{CONCLUSION}

The extension approaches as a technological skills transfer methods that the extension practitioners focus on has to be reviewed, to be guided and underpinned by the adult education approach. The extension practitioners must be familiar with the adult education principles that should guide their practice when engaging with emerging farmers. To humanise the practice, the extension practitioners and the senior staff when engaging with the emerging farmers have to let go off the elements of power and dominance over the emerging farmers and depower themselves. 


\section{RECOMMENDATION}

According to similar findings of this study, adult education principles are not observed to guide the extension approach when providing information to emerging farmers. The envisaged extension approach that the extension practitioner employs when engaging with the emerging farmers has to take into consideration that the emerging farmers are adults and by law are entitled to adult education. Therefore, the extension practitioners should be aware that the emerging farmers come with a massive wealth of knowledge and as adults; their experience needs to be enhanced and not suppressed.

\section{ACKNOWLEDGEMENT}

I wish to acknowledge the agricultural communities in Thaba Nchu and Boshof, Free State Province. I am also grateful to the Extension Officials in Motheo Metro for providing space for the research to take place and for their significant contribution to the study. It is you all who have made the completion of this study possible. I also acknowledge the University of the Free State.

\section{REFERENCES}

AU, K.H. (1998). Social Constructivism and the School Literacy Learning of Students of Diverse Backgrounds, 30(2), 297-319.

BALIN,A, S., BAUMGARTE, D. AND SALNA, E. (2015). The Model for Balancing Learning Workload. Procedia Computer Science, 77, 113-118. https://doi.org/10.1016/j.procs.2015.12.367.

BAUM, F., MACDOUGALL, C., SMITH, D., COMEAU, S., CHEVALIER, J.M., BUCKLES, D.J. AND DIALOGUE, S.A.S. (2010). Participatory action research, (May), 854-857. https://doi.org/10.1136/jech.2004.028662.

BERGOLD, J. AND THOMAS, S. (2012). Participatory Research Methods: A Methodological Approach in Motion. FQS, 13(1), 30.

BURIAK, P. AND SHINN, G.C. (1989). Mission, Initiatives, And Obstacles to Research In Agricultural Education: A National Delphi Using External Decision Makers. Journal of Agricultural Education, 30(4), 14-23. https://doi.org/10.5032/jae.1989.04014.

CRANE, P. (2011). Participatory Action Research Workbook. A workbook designed to support the recording key elements of a Participatory Action Research process. Retrieved from http://eprints.qut.edu.au/view/person /Crane,_Philip.html.

CROTTY, M. 1998. The foundation of social research. London: Sage Publications.

DE BEAUGRANDE, R. (2006). Critical discourse analysis: History, ideology, methodology. Studies in Language and Capitalism, 1(Beaugrande), 29-56. https://doi.org/diskursanalyse; qualitative methode; ideologie.

DUBE, M.M.A. (1993) Perceptions of field officers, extension officers and farmers regarding agricultural extension education in Swaziland, Retrospective Theses and Dissertations. Iowa State University.

DYER, J.E., AND OSBORNE, E.W. (1996). Effects of Teaching Approach on Problem Solving Ability of Agricultural Education Students with Varying Learning Styles. Journal of Agricultural Education, 37(4), 36-43. https://doi.org/10.5032/jae.1996.03043. 
HIDALGO TENORIO, E. (2011). Critical Discourse Analysis, An overview. Nordic Journal of English Studies, 10(1), 183-210.

HOSSAIN, A.K.M., KANANI, P. AND KALSARIYA, B.N. (2018) 'Relationship of farmers' profile with utilization of feedback mechanism of agricultural extension services', Guj. J. Ext. Edu, pp. 128-134.

HUBÍK, S. (1997). Mass Bricolage as a Source of Alternative Education. Towards the Sociology of Education. Czech Sociological Review. 5(1), 57-71.

JANKS, H. (1997). Critical Discourse Analysis as a Research Tool. Discourse: Studies in the Cultural Politics of Education, 18(3), 329-342. https://doi.org/10.1080/0159630970180302.

JOHNSON, S.B., CARTER, H.S. AND KAUFMAN, E.K. (2008) 'Learning styles of farmers and others involved with the Maine Potato Industry', Journal of Extension, 46(4), pp. $1-5$.

KEMMIS, S. AND MCTAGGART, R. (2000). -Participatory action research \| In Handbook of Qualitative Research (2nd ed) (pp. 567-605). CA: SAGE.

KINCHELOE, J. (2001). Describing the Bricolage: Conceptualising a New Rigor in Qualitative Research. Qualitative Research, 7(6), 679-92.

KINCHELOE, J. AND BERRY, K. 2004. (2004). Rigour and Complexity in Qualitative Research: Conceptualising the Bricolage. London: Open University Press.

LI, J., NAUGHTON, J., AND NEHME, R. V. (2015). Resource Bricolage for Parallel Database Systems. Pvldb, 8(1), 25-36. https://doi.org/10.14778/2735461.2735464.

MAHLOMAHOLO, S.M.G. (2013). Naivety of Empiricism Versus Complexity of Bricolage in Creating Sustainable Learning Environments. 6th International Conference of Education, Research and Innovation (Iceri 2013), (November 2013), 4690-4699.

MARTIN, R.A. AND BIN SAJILAN, S. (1989) 'Teaching Competencies Needed By Extension Workers In Transferring Agricultural Technologies To Malaysian Farmers', Journal of Agricultural Education, 30(2), pp. 68-72. doi: 10.5032/jae.1989.02068.

MCTAGGART, R. (1994). Participatory Action Research: issues in theory and practice. Educational Action Research, 2(3), 313-337.

OLADOSU, I.O. (2006) 'Implications of Farmers' Attitude Towards Extension Agents on Future Extension Programme Planning in Oyo State of Nigeria', Journal of Social Sciences, 12(2), pp. 115-118. doi: 10.1080/09718923.2006.11978377.

OWUSU, W.A. AND JANSSEN, F. (2013). Social entrepreneurship: Effectuation and bricolage approaches to venture establishment in west Africa. 4th EMES International Research Conference on Social Enterprise, 1-17. Retrieved from http://www.iapsocent.be/sites/default/files/Owusu \& Janssen ECSP-LG13-42.pdf.

PARÄKYLÄ, A. AND RUUSUVUORI, J. (2011). - Analysing talk and text \| In Handbook of Qualitative Research (4th ed.) (pp. 529-543). CA: SAGE.

SEHRING, J. (2009). Path dependencies and institutional bricolage in post-Soviet water governance. Water Alternatives, 2(1), 61-81.

SÉVERINE LE, L. (2005). Bricolage versus creativity what ${ }^{\mathrm{ee}} \mathrm{s}$ the difference? (RMT (WPS 0502). 19. <hal-00451857>).

TEELE, T., NKOANE, M. AND MAHLOMAHOLO, S. (2020) 'Corollaries of pedagogic praxis on technological skills', Journal of Gender \& Behaviour, 18(1): 1596-9231, pp. $1-12$.

TIRAIEYARI, N. (2010) 'Teaching method competencies used by extensionists in transferring the good agricultural practices to Malaysian farmers', Australian Journal of Basic and Applied Sciences, 4(10), pp. 5379-5387. 
VAN DIJK, T.A. (1998). Critical discourse analysis. Handbook of Discourse Analysis, 17(1), 126-32. https://doi.org/10.2307/3587683.

VAN DIJK, T.A. (1995). Discourse Analysis as Ideology Analysis. In Language and Peace. (pp. 17-33). Dartmouth: Aldershot.

VAN DIJK, T.A. (1997). Critical discourse analysis: new possibilities for scientific research in the mental health area. Revista Latino-Americana de Enfermagem, 17, 126-32. https://doi.org/10.1111/b.9780631205968.2003.00019.x.

WODAK, R. AND MEYER, M. (2009). Discourse analysis: history, agenda, theory, and methodology. Methods for Critical Discourse Analysis, 1, 1-33. 